\title{
Entomopathogenic fungi isolated from agro-ecosystem soil in South Sulawesi, Indonesia
}

\author{
Tamrin Abdullah, Irwan Irwan, Tutik Kuswinanti, Itji Diana Daud, Asman Asman*, Andi Nasruddin, \\ Nurariaty Agus \\ Department of Plant Pests and Diseases, Faculty of Agriculture, Hasanuddin University, Makassar, Indonesia
}

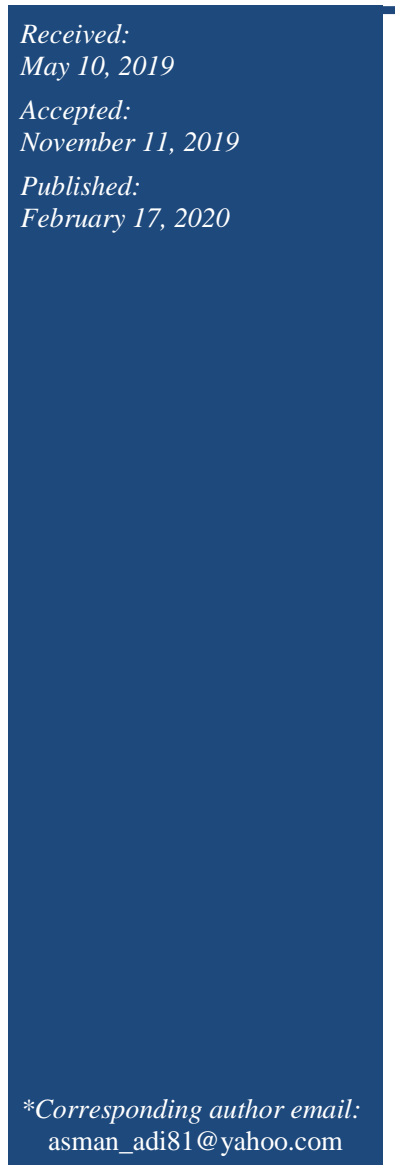

\begin{abstract}
Entomopathogenic fungi have been proved controlling plant pests, and most of the entomopathogenic fungi isolated from the agroecosystem. The research was carried out to characterize the entomopathogenic fungi diversity associated with different agroecosystem on a different location in South Sulawesi, Indonesia. Fungi of rice field ecosystems were found more diverse than on dryland ecosystems, and the genus was Fusarium species, Aspergillus species, Rhizopus species, Trichoderma species, Penicillium species, Rhizoctonia species and Metharizium species. Moreover, Fusarium species and Rhizopus species were the most frequent genus isolated from rice field ecosystem, while on dryland ecosystems, the fungus of Metharizium species found more frequent than Fusarium species and Aspergillus species According to a geographical location on rice field ecosystems. The number of fungi isolated on the regency of Gowa more numerous than regency of Sidrap, Takalar, and Pinrang. Meanwhile, on the dryland ecosystems, three locations were the city of Makassar, the regency of Maros, and the regency of Polman. Among three areas, the regency of Maros founded more fungi than regency of Polman and Makassar. This study exhibits the diversity of fungi on the rice field, and dryland ecosystems were quite different.
\end{abstract}

Keywords: Entomopathogenic fungi, Agroecosystem soil, Diversity, South Sulawesi

\section{How to cite this:}

Abdullah T, Irwan I, Kuswinanti T, Daud DI, Asman A, Nasruddin A and Agus N, 2020. Entomopathogenic fungi isolated from agro-ecosystem soil in South Sulawesi, Indonesia. Asian J. Agric. Biol. 8(1):17-23. DOI: 10.35495/ajab.2019.05.197

This is an Open Access article distributed under the terms of the Creative Commons Attribution 3.0 License. (https://creativecommons.org/licenses/by/3.0), which permits unrestricted use, distribution, and reproduction in any medium, provided the original work is properly cited.

\section{Introduction}

Soil microorganisms services have significant influences on agricultural ecosystems, including soil formation, nutrient cycling, and biological control of pathogens and pests (Lehman et al., 2015). Soil microbial communities are closely associated with plant communities as the plant is an essential source of energy for most microorganisms through root exudates and plant waste (Schenck zu SchweinsbergMickan et al., 2012; Singh et al., 2016), and type of plant is one of the elements that control the activity of soil microbial (Mitchell et al., 2012; Cline and Zak, 2015).

Entomopathogenic fungi are commonly found in soil including agroecosystem soil. The fungi often isolated from soil and insects in the field (Keller and Zimmerman, 1989). One of the famous 
entomopathogenic genera is Metarhizium. They are common rhizosphere colonizers fungus in many ecosystems (Bruck, 2010). Furthermore, the entomopathogenic fungi were abundant in soil, and they were isolated from $32 \%$ of soil specimens gathered from distinct cultivated habitats across Finland (Vanninen et al., 1989). In addition, Metarhizium anisopliae isolated from $31 \%$ of soil samples taken from pastures across Tasmania (Rath et al., 1992). Chandler et al. (1997) isolated the fungus into $17.5 \%$ of soil specimens in the United Kingdom. Moreover, entomopathogenic fungi isolated from $14.9 \%$ of soil samples in Italy (Tarasco et al., 1997).

Biological control through the application of entomopathogenic fungi have been recommended as promising agents for managing insect pests (Gaugler, 2002). Several fungal entomopathogens have proven to reduce the infestation of several insects pests such as Metarhizium anisopliae, and Beauveria bassiana was applied against many different types of insect pests (Migiro et al., 2010; Rondot and Reineke, 2018).

Isolation and characterization of entomopathogenic fungi local species should be conducted to gain more information about them. So their plentifulness, dispersal, and their function in the local environment can be studied. Accordingly, our objective was to explore and evaluate the abundance and the diversity of entomopathogenic fungus on the rice field and dryland ecosystems in South Sulawesi, Indonesia.

\section{Material and Methods}

Soil samples were collected from different agroecosystems situated in South Sulawesi Indonesia (Figure 1) and from habitats of rice field and dryland ecosystems including cacao, cassava, banana, lemongrass, and weed vegetation (Table 1 and 2) during February until September 2017. Soil Samples were taken in the field by digging a hole at $10-15$ $\mathrm{cm}$ in depth using a shovel in an area of $1000 \mathrm{~m}^{2}$ around plant roots environment. Samples were kept in the plastic bag $(25 \times 25 \mathrm{~cm})$ about $0.5 \mathrm{Kg}$ in weight and tightly closed to prevent dryness.

\section{Isolation of entomopathogenic fungi}

Isolation of entomopathogenic fungi was carried out by collecting soil samples by "baiting" them with the larvae of darkling beetle, Tenebrio molitor (Tenebrionidae: Coleoptera). Ten larvae of the third instar Tenebrio molitor were put into a small container filled by moist soil samples. Next, The cover of the container was replaced with the smooth net as the lid. Then, the container with ten larvae was kept at room temperature in dark condition for two weeks. During the incubation process, the larvae in the container were moistened by water through the spraying method every morning, 09.00 am and afternoon, $05.00 \mathrm{pm}$.

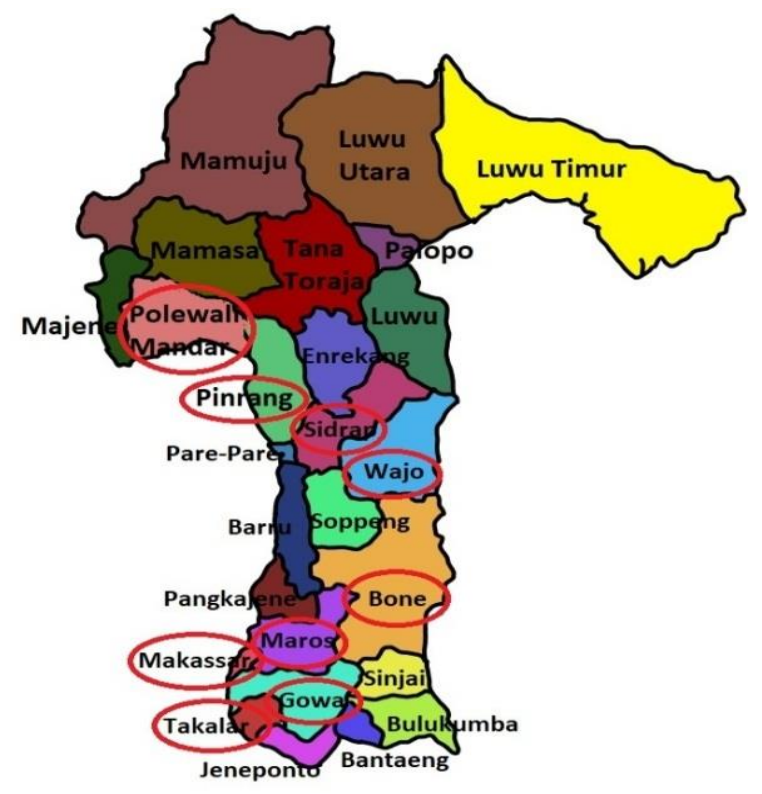

Figure-1: Map of sampling sites in South Sulawesi, Indonesia where soil collected for isolation of fungal entomopathogen (enclosed circles).

Soil sampling

After 5-14 days, the larvae of darkling beetle was fathomed infected by fungi with an indication showing mycelia on their body surfaces were collected and maintained in the small tubes. All of the infected larvae were surface-sterilized by ethanol $70 \%$ for $3-5$ second and in sterile water for $5-10$ second. Then, the larvae were dried with sterile absorbent paper and put them into Petri dish contain moist tissue. Fungal isolation was made on Potato Dextrose Agar (PDA) containing chloramphenicol as antibiotics in a petri dish. After that, they are incubated at room temperature in darkness. Finally, the isolates were subcultured and identified. 
Table-1: Site descriptions where soil collected for isolation of fungal entomopathogen on rice field ecosystems.

\begin{tabular}{|c|l|l|}
\hline No & \multicolumn{1}{|c|}{ Location } & \multicolumn{1}{|c|}{$\begin{array}{c}\text { Environmental } \\
\text { details }\end{array}$} \\
\hline 1 & $\begin{array}{l}\text { The village of Tonronge, } \\
\text { District of Baranti, } \\
\text { Regency Sidrap }\end{array}$ & $\begin{array}{l}\text { - Irrigated rice field } \\
\text { - Rice phase was } \\
\text { Generative }\end{array}$ \\
\hline 2 & $\begin{array}{l}\text { The village of Patalassang, } \\
\text { District of Samata, } \\
\text { Regency Gowa }\end{array}$ & $\begin{array}{l}\text { - Irrigated rice field } \\
\text { - Rice phase was } \\
\text { Generative }\end{array}$ \\
\hline 3 & $\begin{array}{l}\text { The village of Tanah } \\
\text { Bangka,District of Bajeng } \\
\text { Barat, Regency Gowa }\end{array}$ & $\begin{array}{l}\text { - Irrigated rice field } \\
\text { - Rice phase was } \\
\text { Generative }\end{array}$ \\
\hline 4 & $\begin{array}{l}\text { The village of Galesong } \\
\text { Barat, } \\
\text { District of Galesong, } \\
\text { Regency Takalar }\end{array}$ & $\begin{array}{l}\text { - Irrigated rice field } \\
\text { - Rice phase was } \\
\text { Generative }\end{array}$ \\
\hline 5 & $\begin{array}{l}\text { The village of Aressie, } \\
\text { District of Tiroang, } \\
\text { Regency Pinrang }\end{array}$ & $\begin{array}{l}\text { - Irrigated rice field } \\
\text { - Rice phase was } \\
\text { Generative }\end{array}$ \\
\hline
\end{tabular}

Table-2: Site descriptions where soils collected for isolation of fungal entomopathogen on dryland ecosystems.

\begin{tabular}{|c|c|c|}
\hline No & Location & Environmental details \\
\hline 1 & $\begin{array}{l}\text { The village of Tapango } \\
\text { Barat, } \\
\text { District of Tapango, } \\
\text { Regency of Polewali } \\
\text { Mandar (Polman) }\end{array}$ & $\begin{array}{l}\text { Cacao farm, None of } \\
\text { pesticides application in } \\
\text { the last past seven } \\
\text { years, and surrounded } \\
\text { by elephant grass } \\
\text { (Pennisetum } \\
\text { purpureum). }\end{array}$ \\
\hline 2 & $\begin{array}{l}\text { The village of Purnakarya, } \\
\text { District of Tanralili, } \\
\text { Regency of Maros }\end{array}$ & $\begin{array}{l}\text { Cacao farm, None of } \\
\text { pesticides application. }\end{array}$ \\
\hline 3 & $\begin{array}{l}\text { The village of Samangi } \\
\text { Balangajia, } \\
\text { District of Simbang, } \\
\text { Regency of Maros }\end{array}$ & Banana farm. \\
\hline 4 & $\begin{array}{l}\text { The village of Samboeja, } \\
\text { District of Simbang, } \\
\text { Regency of Maros }\end{array}$ & Lemongrass farm. \\
\hline 5 & $\begin{array}{l}\text { The village of Samanngi } \\
\text { Balangajia, } \\
\text { District of Simbang, } \\
\text { Regency of Maros }\end{array}$ & $\begin{array}{l}\text { Weeds and elephant } \\
\text { grass vegetation. }\end{array}$ \\
\hline 6 & $\begin{array}{l}\text { The village of Samanngi } \\
\text { Balangajia, } \\
\text { District of Simbang, } \\
\text { Regency of Maros }\end{array}$ & $\begin{array}{l}\text { Bamboo vegetation and } \\
\text { the area used disposal } \\
\text { chicken manure. }\end{array}$ \\
\hline 7 & $\begin{array}{l}\text { The village of Bangkala, } \\
\text { District of Manggala, } \\
\text { City of Makassar }\end{array}$ & $\begin{array}{l}\text { Cassava and banana } \\
\text { farm. }\end{array}$ \\
\hline
\end{tabular}

\section{Identification of entomopathogenic fungi}

The fungi that emerged mainly characterized based on their morphological of macroscopic (colour, shape, and colony growth) and microscopic (conidia) according to Barnet and Hunter, 1972.

\section{Results}

The result of fungi isolation and identification through baiting method on two different areas showed that six genera of fungi were found on rice field ecosystems and three genera on dryland ecosystems (Table 3). Overall, fungi on rice field ecosystems are more diverse than on dryland ecosystems; However, on dryland ecosystems was isolated famous entomopathogenic fungus, Metharizium species.

Table-3: Diversity entomopathogenic fungi in soil samples related to types of ecosystems.

\begin{tabular}{|c|c|l|}
\hline \multirow{2}{*}{ Ecosystem } & \multicolumn{2}{|c|}{ Fungi isolates } \\
\cline { 2 - 3 } Rice field & No. of & \multicolumn{1}{|c|}{ Fungi Genera } \\
\hline & 6 & $\begin{array}{l}\text { Fusarium species, Aspergillus } \\
\text { species isolate 1, Aspergillus } \\
\text { species isolate 2, Rhizopus } \\
\text { species, Trichoderma species, } \\
\text { Penicillium species, } \\
\text { Rhizoctonia species }\end{array}$ \\
\hline Dryland & 3 & $\begin{array}{l}\text { Metharizium species, } \\
\text { Aspergillus species isolate 1, } \\
\text { Fusarium species }\end{array}$ \\
\hline
\end{tabular}

Six fungal genera were identified both on the rice field and dryland ecosystems (Tabel 3) namely Fusarium species, Aspergillus species, Rhizopus species, Trichoderma species, Penicillium species, Metharizium species and Rhizoctonia species. The fungi were identified based on morphological character including colony appearance (Figure 2).

Among the fungi that infects larvae of Tenebrio molitor (Figure 3) from rice field ecosystems soil, genus of Fusarium, Rhizopus, and Aspergillus species isolate 1 were the most often fungi that isolated from infected larvae of Tenebrio molitor; which is Fusarium species was the most prevalent isolates recovered comprise $31 \%$ of the total isolates, followed by Rhizopus species (27\%) and Aspergillus species isolate $1,23 \%$. Then, Trichoderma species (8\%) and Penicillium species, Rhizoctonia species, Aspergillus species isolate 2 with frequency $4 \%$ each on rice field land agroecosystem (Figure 4). 
Meanwhile, on dryland ecosystems soil, Genus of Metharizium and Aspergillus showing the higher rate of emerged fungi. Which is Metharizium species was the most frequent isolate $(50 \%)$, followed by Aspergillus species isolate $1(41.7 \%)$ and Fusarium species $8.3 \%$ (Figure 5).

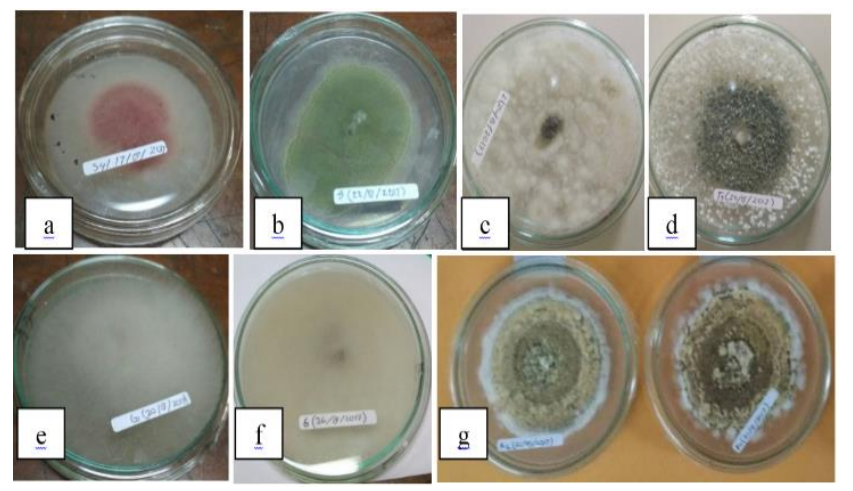

Figure-2: Colony of various fungi genera on PDA Medium; a. Fusarium; b. Aspergillus; c. Aspergillus; d. Trichoderma;e. Penicilium; f. Rhizopus; g. Metarhizium.

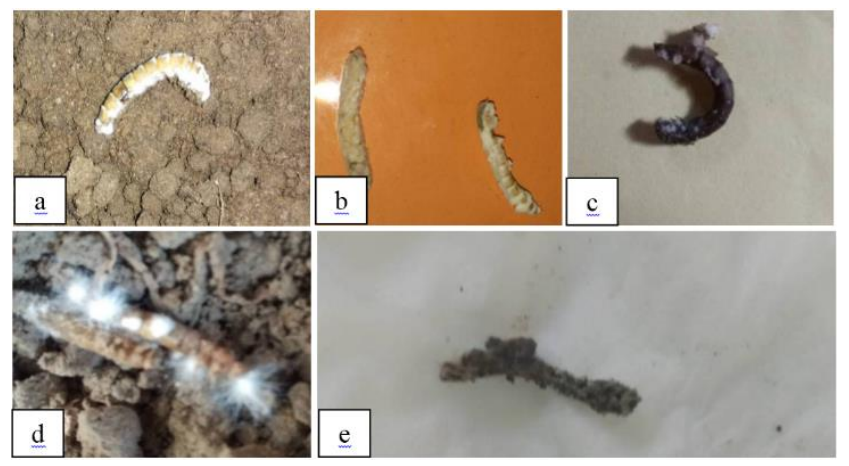

Figure-3 Tenebrio molitor larvae infected by various fungi; a. Metarhizium; b. Aspergillus; c. Fusarium; d. Rhizopus; e. Trichoderma.

According to the geographical location, the fungi isolates on rice field ecosystems soil distributed more numerous and diverse in Gowa site. Six different isolates of fungi that isolated from infected Tenebrio molitor larvae, which is Aspergillus isolates 1, and
Rhizopus shows significant numbers, rather than other isolates such as Fusarium, Aspergillus isolates 2, Trichoderma, Penicillium, Rhizoctonia. In Takalar site, there are four different isolates found infects Tenebrio molitor larvae and the number of the population not significant to Pinrang and Sidrap site. The least fungal microbes found in Pinrang and Sidrap site, one and two different isolates, respectively (Table 4).

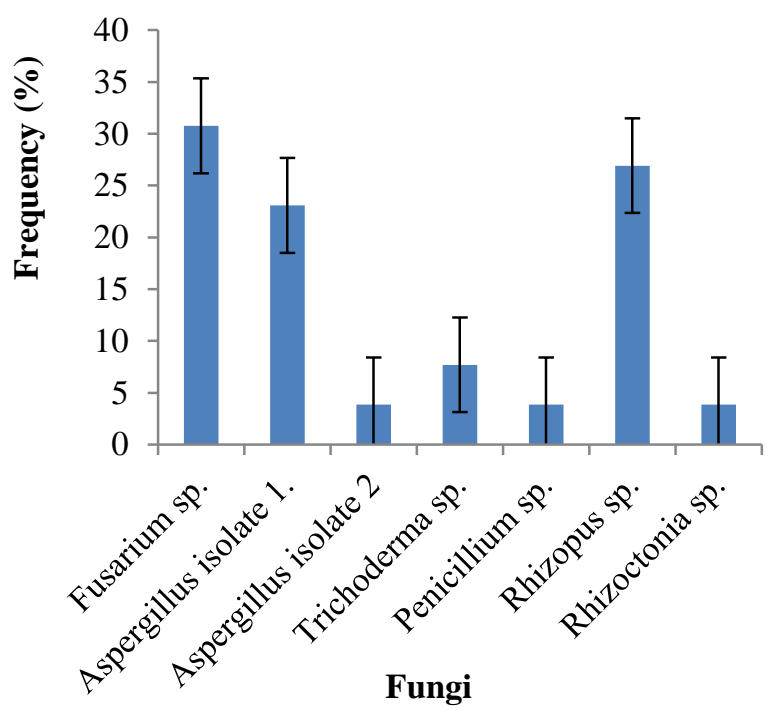

Figure-4: The frequency occurrence $(\%)$ of entomopathogenic fungi isolated from rice field ecosystems soil in South Sulawesi, Indonesia

Meanwhile, on the dryland ecosystems soil, among three different sites sample, Maros was the most common area that found three isolates of fungus namely Fusarium, Aspergillus, Metharizium followed by Polman and Makassar that found two isolates (Table 5). Metharizium isolated more frequent than two other isolates and the number not significantly different both in Maros and Polman. Aspergillus was isolated in Maros, Polman, and Makassar. However, the number was high in Maros and Polman while Fusarium was found only in Maros and Makassar with a small number.

Table-4: Distribution of entomopathogenic fungi in soil samples according to the geographical location on rice field ecosystems.

\begin{tabular}{|c|c|c|c|c|c|c|c|}
\hline Site & Fusarium & Aspergillus Isolate 1 & Aspergillus Isolate 2 & Trichoderma & Penicillium & Rhizopus & Rhizoctonia \\
\hline Sidrap & $1^{\mathrm{ns}}$ & $1^{\mathrm{b}}$ & $0^{\mathrm{ns}}$ & $0^{\mathrm{ns}}$ & $0^{\mathrm{ns}}$ & $0^{\mathrm{b}}$ & $0^{\text {ns }}$ \\
\hline Gowa & $3^{\mathrm{ns}}$ & $5^{\mathrm{a}}$ & $1^{\mathrm{ns}}$ & $1^{\mathrm{ns}}$ & $1^{\mathrm{ns}}$ & $5^{\mathrm{a}}$ & $0^{\mathrm{ns}}$ \\
\hline Takalar & $1^{\mathrm{ns}}$ & $0^{\mathrm{b}}$ & $0^{\mathrm{ns}}$ & $1^{\mathrm{ns}}$ & $0^{\mathrm{ns}}$ & $2^{\mathrm{b}}$ & $1^{\mathrm{ns}}$ \\
\hline Pinrang & $3^{\mathrm{ns}}$ & $0^{\mathrm{b}}$ & $0^{\mathrm{ns}}$ & $0^{\mathrm{ns}}$ & $0^{\mathrm{ns}}$ & $0^{\mathrm{b}}$ & $0^{\mathrm{ns}}$ \\
\hline
\end{tabular}

Numbers in the same column followed by the same letters are not significantly different ( $\mathrm{P}<0.05$, LSD test). 


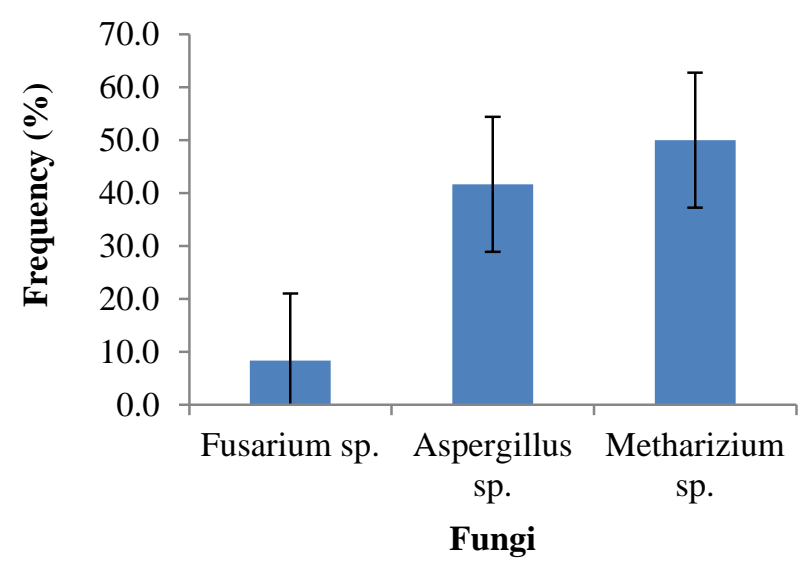

Figure-5: The frequency occurrence $(\%)$ of entomopathogenic fungi isolated from dryland ecosystems soil in South Sulawesi, Indonesia

Table-5: Distribution of entomopathogenic fungi in soil samples according to the geographical location on dryland ecosystems.

\begin{tabular}{|c|c|c|c|}
\hline Site & Fusarium & Aspergillus & Metharizium \\
\hline Makassar & 1 & $1^{\mathrm{b}}$ & $0^{\mathrm{b}}$ \\
\hline Maros & 1 & $5^{\mathrm{a}}$ & $6^{\mathrm{a}}$ \\
\hline Polman & 0 & $4^{\mathrm{ab}}$ & $6^{\mathrm{a}}$ \\
\hline
\end{tabular}

Numbers in the same column followed by same letters are not significantly different $(\mathrm{P}<0.05$, LSD test).

\section{Discussion}

This study compared the diversity and frequency of entomopathogenic fungi on different ecosystems. Several fungi associated with the rice field ecosystems and its found more diverse than dryland ecosystems. Genus of Fusarium, Aspergillus, and Rhizopus dominated the emerged fungus on the rice field ecosystems. However, on dryland ecosystems founded one of the widespread fungi that use as a biological control widely for plant pests namely Metharizium species. Structure of soil microbial community is affected by a number of associating elements including type of plant (Maul and Drinkwater, 2010), agricultural practices (Buyer et al., 2010; Treonis et al., 2010; Maul et al., 2014), Fertilization, and soil properties (Lauber et al., 2008 \& 2009; Freedman and Zak, 2015).

Geographical distributions can influence different species of fungi, and these distributions do depend on the environment such as land use change, pollution, pesticides, fertilizers, movement of biota, vegetation, and climate change (Boddy, 2016). Furthermore, the movement of microbes in rice soil is affected by a type of agro-climatic circumstances and agricultural practices including puddling (Banerjee et al., 2006). The activity of microorganisms in rice field soil also affected by transplanting, dosage and frequency of application of chemical fertilizers, biofertilizers, pesticides and duration of drying/flooding stages during crop growth (Prasanna et al., 2012). Regarding our result on soil sample sites of the rice field ecosystems, the number of fungi isolated on Gowa was more diverse than other places. Whereas sites with the least amount of fungi isolated were Sidrap and Pinrang; Sidrap and Pinrang sites are the most intensive planting areas of rice in South Sulawesi Province. Meanwhile, the type of plant and chemical input influence the composition of the microbes of the dryland Maros, Polman, and Makassar sites.

Aspergillus species and Fusarium species consistently isolated both rice field and dryland soil. Aspergillus species has been known as one of the entomopathogenic fungi around the world, it proven inhibited and to be pathogenic to insect pests of various families and few-mode of action (Tanada and Kaya, 1993; Buhroo et al., 2002; Seye et al., 2009: Suliman and Osman, 2012; Seye et al., 2014). Similarly, the genus of Fusarium has been reported virulent to insect pests (Tanada and Kaya, 1993; Anand and Tiwary, 2014). Also, Aspergillus species and Fusarium species reported to be associated with a number of dryland tissue plants and have endophytic properties including cacao (Rubini et al., 2005; Asman et al., 2018). Meanwhile, well known entomopathogenic fungi, Metharizium species isolated only from the dryland soil. One of the famous taxa is Metarhizium anisopliae. It has been used as biological control agents for insects pest widely (Migiro et al., 2010; Anand and Tiwary, 2014).

Our results indicate that agroecosystems can have different soil microbial communities structure both in the rice field and dryland soil. More research will be needed to specify if these entomopathogenic fungi have significant role protects plants from various insect pests. 


\section{Conclusion}

This study demonstrates that a number of entomopathogenic fungi found to be associated with both rice field land and dryland ecosystem. Therefore, these native entomopathogenic fungi could be a promising source of biological control for insect pests.

\section{Acknowledgement}

The authors would like to thank the Ministry of Research, Technology and Higher Education, the Republic of Indonesia for financial support through the PTUPT Research Scheme, administered by the Institute of Research and Community Services (LPPM) Hasanuddin University, Makassar, Indonesia

Disclaimer: None.

Conflict of Interest: None.

Source of Funding: Ministry of Research, Technology and Higher Education, Republic of Indonesia through the PTUPT Research Scheme.

\section{References}

Asman A, Amin N, Rosmana A and Abdullah T, 2018. Endophytic fungi associated with cacao branch and their potential for biocontrol vascular streak dieback disease on cacao seedling. Conf. Ser.: Earth Environ. Sci. doi:10.1088/17551315/157/1/012039

Anand R and Tiwary BN, 2009. Pathogenicity of entomopathogenic fungi to eggs and larvae of Spodoptera litura, the common cutworm, Biocont. Sci. Technol. 19: 919-929.

Barnet HL and Hunter BB, 1972. Illustrated Genera of Imperfect Fungi, 3rd Ed. Burgedd Publishing Company, Minnesota, USA.

Banerjee B, Aggarwal PK, Pathak H, Singh AK and Chaudhary A, 2006. Dynamics of organic carbon and microbial biomass in alluvial soil with tillage and amendments in rice-wheat systems. Environ. Monit. Assess. 119:173-189.

Boddy L, 2016. Fungi, Ecosystems, and Global Change, The Fungi, 3rd Ed. Academia Press. Elsevier Ltd.

Bruck DJ, 2010. Fungal entomopathogens in the rhizosphere. Biocontrol. 55:103-112.

Buhroo AA, Chishti MZ and Masoodi MA, 2002.
Biocontrol agents of shot-hole borer, Scolytus nitidus Schedl. (Coleoptera: Scolytididae) infesting apple orchards. Indian J. Plant Prot. 30: 71-73.

Buyer JS, Teasdale JR, Roberts DP, Zasada IA and Maul JE, 2010. Factors affecting soil microbial community structure in tomato cropping systems. Soil Biol. Biochem. 42: 831- 841.

Chandler D, Hay D and Reid AP, 1997. Sampling and occurrence of entomopathogenic fungi and nematodes in UK soils. Appl. Soil Ecol. 5: 133141.

Cline LC and Zak DR, 2015. Soil microbial communities are shaped by plant-driven changes in resource availability during secondary succession. Ecol. 96: 3374-3385

Freedman Z and Zak DR, 2015. Soil bacterial communities are shaped by temporal and environmental filtering: evidence from a longterm chronosequence. Environ. Microbiol. 17: 3208-3218.

Gaugler R, 2002. Entomopathogenic Nematology, CABI Publishing, Wallingford, UK.

Keller S and Zimmerman G, 1989. Mycopathogens of soil insects. In: N. Wilding, N.M. Collins, P.M. Hammond and J.F. Webber (Editors), InsectFungus Interactions, Academic Press, London, UK.

Lauber CL, Strickland MS, Bradford MA and Fierer $\mathrm{N}, 2008$. The influence of soil properties on the structure of bacterial and fungal communities across land-use types. Soil Biol. Biochem. 40: 2407-2415.

Lauber CL, Hamady M, Knight R and Fierer N, 2009. Pyrosequencing-based assessment of soil $\mathrm{pH}$ as a predictor of soil bacterial community structure at the continental scale. Appl. Environ. Microbiol. 75: 5111-5120

Lehman RM, Cambardella CA, Stott DE, AcostaMartinez V, Manter DK, Buyer JS, Maul, JE, Smith JL, Collins HP, Halvorson JJ, Kremer RJ, Lundgren JG, Ducey TF, Jin VL, and Karlen DL, 2015. Understanding and enhancing soil biological health: the solution for reversing soil degradation. Sustainability. 7: 988-1027.

Maul J and Drinkwater L, 2010. Short-term plant species impact on microbial community structure in soils with long-term agricultural history. Plant Soil. 330: 369-382.

Maul JE, Buyer JS, Lehman RM, Culman S, Blackwood CB, Roberts DP, Zasada IA and 
Teasdale JR, 2014. Microbial community structure and abundance in the rhizosphere and bulk soil of a tomato cropping system that includes cover crops. Appl. Soil Ecol. 77: 42-50.

Migiro LN, Maniania NK, Chabi-olaye A and Vandenberg J. 2010. Pathogenicity of Entomopathogenic Fungi Metarhizium anisopliae and Beauveria bassiana (Hypocreales: Clavicipitaceae) Isolates to the Adult Pea Leafminer (Diptera: Agromyzidae) and Prospects of an Autoinoculation Device for Infection in the Field. Environ. Entomol. 39: 468-475.

Mitchell R, Hester A, Campbell C, Chapman S, Cameron C, Hewison R and Potts J, 2012. Explaining the variation in the soil microbial community: do vegetation composition and soil chemistry explain the same or different parts of the microbial variation? Plant Soil. 351: 355-362.

Prasanna R, Nain L, Pandey AK and Saxena AK, 2012. Microbial diversity and multidimensional interactions in the rice ecosystem. Arch. Agron. Soil Sci. 58: 723-744.

Rath AC, Koen TB and Yip HY, 1992. The influence of abiotic factors on the distribution and abundance of Metarhizium anisopliae in Tasmanian pasture soils. Mycol. Res. 96: 378384.

Rondot Y and Reineke A, 2018. Endophytic Beauveria bassiana in grapevine Vitis vinifera (L.) reduces infestation with piercing-sucking insects. Biol. Control. 116: 82-89.

Rubini MR, Silva-ribeiro RT, Pomella AWV and Maki CS, 2005. Diversity of endophytic fungal community of cacao (Theobroma cacao L.) and biological control of Crinipellis pernicious, causal agent of Witches Broom Disease. Int. J. Biol. Sci. 1: 24-33.

Schenck zu Schweinsberg-Mickan M, Jörgensen RG and Müller T, 2012. Rhizodeposition: its contribution to microbial growth and carbon and nitrogen turnover within the rhizosphere. J. Plant Nutr. Soil Sci. 175: 750-760.

Seye F, Faye O, Ndiaye M, Njie E and Afoutou JM, 2009. Pathogenicity of the fungus, Aspergillus clavatus, isolated from the locust, Oedaleus senegalensis, against larvae of the mosquitoes Aedes aegypti, Anopheles gambiae and Culex quinquefasciatus. J Insect Sci. 9: 1-7.

Seye F, Thomas B, Slimane B, Jean-Yves Z, Mady N, Frank D and Frederic F, 2014. Effect of entomopathogenic Aspergillus strains against the pea aphid, Acyrthosiphon pisum Hemiptera: Aphididae). Appl. Entomol. Zool. 49: 453-458.

Singh K, Trivedi P, Singh G, Singh B and Patra DD, 2016. Effect of different leaf litters on carbon, nitrogen and microbial activities of sodic soils. Land Degrad. Dev. 27:1215 - 1226.

Suliman EA and Osman YM, 2012. The activity of Aspergillus terreus as Entomopathogenic Fungi on Different stages of Hyalomma anatolicum under Experimental Conditions. J. Entomol. 9: $343-351$.

Tanada Y and Kaya HK, 1993. Insect Pathology. Academic Press, San Diego, USA.

Tarasco E, Bievre CD, Papierok B, Poliseno M and Triggiani O, 1997. Occurrence of entomopathogenic fungi in soils in Southern Italy. Entomologica. 31: 157- 166.

Treonis AM, Austin EE, Buyer JS, Maul JE, Spicer L and Zasada IA, 2010. Effects of organic amendment and tillage on soil microorganisms and microfauna. Appl. Soil Ecol. 46: 103-110.

Vanninen I, Husberg GB and Hokkanen HMT, 1989. Occurrence of entomopathogenic fungi and entomoparasitic nematodes in cultivated soils in Finland. Acta Entomol. Fenn. 53: 65-71.

\section{Contribution of Authors}

Abdullah T: Conceived idea, designed research methodology, manuscript writing and final approval Irwan I: Data collection Kuswinanti T: Designed research methodology and Variable Assessment Method Daud DI: Data interpretation and analysis Asman A: Manuscript writing and final approval, statistical analysis and literature search Nasruddin A: Manuscript final reading \& approval and data interpretation \& analysis Agus N: Designed research methodology and Variable Assessment Method 